\title{
The Application of Analytical Technique of Gas Chromatography and Geochemical Pyrolysis in Low Permeability Oilfields
}

\author{
Yining Wang \\ Beijing Engineering Technology Center of China Geological Energy Group, Beijing 100083, China
}

Wenbo Liu

Sinopec International Petroleum of SINOPEC, Beijing 100083, China

Shaobo Zhang

Pingbei management department, Jianghan Oilfield Branch Company of SINOPEC, Shanan 717408, China

\section{Man Teng}

Reservoir technique office, oil field production department

China National Offshore Oil Corporation (CNOOC) 065201, China

\author{
Received: August 26, 2011 Accepted: September 10,2011 Published: March 1, 2012 \\ doi:10.5539/jgg.v4n1p250 URL: http://dx.doi.org/10.5539/jgg.v4n1p250
}

\begin{abstract}
The reservoir of low permeability oilfields is thin and its physical property is poor. The oil-water relationship is complex. It is very difficult to classify oil, gas and water layer and the coincidence rate of interpretation is very low. It can no longer meet the needs of reservoir development only dependent on logging data. Through sidewall coring logging in uncertain layers in the area with complex oil-water relationship and statistic analysis on interpretation results based on geochemical pyrolysis and gas chromatography analysis, the authors think the technique can effectively improve the coincidence rate of oil, gas and water interpretation in uncertain layers in low permeability oilfields, realize fine evaluation of reservoirs, help us formulate reasonable drilling solution and enhance the development benefit of oilfields.
\end{abstract}

Keywords: Sidewall coring, Geochemical pyrolysis, Gas chromatography

\section{The Contents of Rock Geochemical Pyrolysis Technique}

Rock pyrolysis technique is a method that carries out pyrolysis chromatography analysis and gas chromatography analysis on sidewall coring sample and makes use of these analysis data to establish the means for calculating the oil saturation of reservoir and judge the reservoir properties of crude oil, establish the relationship between the viscosity and density of crude oil and geochemical pyrolysis, establish the standard for identifying oil and water layer and establish the reservoir productivity prediction method connecting with log information.

\subsection{Parameters of Geochemical Pyrolysis}

Quantitative assessment parameters are the basis of carrying out qualitative interpretation of oil, gas and water and preferences evaluation. Currently, the main parameters applied by rock pyrolysis technique are: $S_{T}, S_{1} / S_{2}$,

$H P I, R t, Q, \phi_{e}, K, S_{w}, S_{w i}, S_{w m}, S_{O}, S_{o m}, S_{o r}, \mu, H_{o}, D P, J P$.

1) total hydrocarbon value: $S_{T}=S_{0}+S_{1}+S_{2}$, which reflects oil-abundance of the rock;

2) the ratio between light and heavy crude oil: $P S=S_{1} / S_{2}$, which reflects the properties of crude oil;

3) yield index: $O P I=S_{1} /\left(S_{0}+S_{1}+S_{2}\right)$;

4) $H P I=S_{2} /\left(S_{0}+S_{1}+S_{2}\right)$ has the good correlation with the viscosity of crude oil, which can reflect the viscosity; 
$\operatorname{Lg} \mu=2.989 H P I+0.175$, correlation coefficient $R=0.953$ (Western outlying areas)

5) Reservoir resistivity $R t$ : For middle-shallow reservoir group, induction log is better than later log for thick sandstone, while later log parameters should be chosen for thin sandstone because induction log is affected greatly by the wall rock.

6) Production index: $Q=\left(\phi_{N}-\phi_{D}\right) / \phi_{N}$, the number of production index $Q$ is lower, which reflects that the lithology is purer and less mud is contained and the capacity is higher whereas, the capacity is lower.

7) Effective porosity: $\phi_{e}=\left\{1-\left(\rho_{\text {岩 }} / \rho_{\text {骨 }}\right) \times\left(W_{\text {后 }} / W_{\text {前 }}\right)\right\} \times 0.8 \times 100 \%$;

8) Total water saturation: $S_{w}^{n}=a \cdot R_{w} / \phi^{m} \cdot R t$;

9) Mobile water saturation: $S_{w m}=S_{w}-S_{w i}$;

10) Oil saturation: $S_{0}=\left(S_{T} \cdot \rho_{\text {岩 }} \cdot 10\right) /\left(\rho_{\text {油 }} \cdot \phi_{e}\right)$;

11) Mobile oil saturation: $S_{0 m}=\left(S_{T} \cdot \rho_{\text {岩 }} \cdot 10\right) /\left(\rho_{\text {油 }} \cdot \phi_{e}\right)$, where $S_{T}=S_{0}+S_{1}+S_{2}$;

12) Residual oil saturation: $S_{o r}=S_{o}-S_{o m}$

\subsection{Characteristics of Gas Chromatogram for Reservoirs with Different Liquid Properties}

1) Oil layer: The peak shape presents evident normal distribution characteristics. The front and end are all full, the base line is straightness and the end has no evident vault.

2) Oil and water layer: The peak shape does not distribute symmetrically. The front is full, the end of the peak declines evidently, the base line is not straightness and the end has evident vault.

3) Water layer: The front and end all have evident vault. The peak shape is not full and the main peak extrude evidently.

\subsection{The Standards for Identifying Oil and Water Layer Quantitatively}

According to the sidewall coring pyrolysis materials of each block, the method for predicting reservoir productivity and the standard for explaining oil and water layer in the region of Tahala-Yingtai, Longbei and Xinzhao have been established at present.

1) The qualitatively interpretation standards for Putaohua and Saertu oil and water layer in the western region.

\subsection{Interpretation Plates of Each Reservoir Group in the Western Region}

The dynamic interpretation and production evaluation plates of each block are established according to logging and try oil materials.

1) The interpretation plate of $1 \#$ block

2) Quantitative evaluation plate of 2\# block

The plate is used in the production promotion when it is established. It interprets seven new wells and accords with 15 of the 19 layers. The coincidence rate is $78.90 \%$ with higher accuracy.

3) Quantitative interpretation plate of 3\# block

\section{Application Results}

\subsection{The Application of Reservoir Quantitative Evaluation Method Greatly Increased the Interpretation} Coincidence Rate of New Wells

At present, the application of rock pyrolysis technology explained 122 complicated wells and analyze 32 sidewall coring layer of 14 evaluation wells which have try oil materials. The results accord with 23 layers and the coincidence rate is $71.9 \%$. The launch of perforating 29 development well have been undergone statistical analysis, in which, 11 of 15 sidewall coring layers in the 5 development wells with ring test data accord with the results and the coincidence rate is $73.3 \%$, for the 24 wells with no ring test data, according to the statistical properties of liquid producing wells, 20 wells accord with the result and the coincidence rate is $83.3 \%$, the specific situation is shown is Table 4:

From the statistical results of table we can see that, the application effect is very good, which improves the coincidence rate of interpretation and makes up the lacks of logging data, and thus better guides the oil-water distribution laws of complex oilfields and recognition of oil reservoir geological characteristics.

\subsection{Accurate Solution to the Oil Reservoir Water Recognition Using Logging Data}

According to the logging, number 56 layer of 14\# Fuyu oil layer is interpreted as oil layer and number 58 layer is interpreted as water layer. Sandstone can be seen in sidewall coring. According to the sidewall coring physical 
and geochemical pyrolysis analysis, number 56 layer has good oil-bearing and should be regarded as oil layer characteristics, while number 58 layer layer has worse oil-bearing than number 56 layer and oil abundance become low from up to down, and it is considered that connecting with the regional data analysis this layer products a small amount of oil and oil and water outflow at the same time under pressure influenced by water, which can be interpreted as oil and water layer comprehensively. The conventional tests confirmed that number 58 layer products oil of $0.025 \mathrm{t}$ for one day and the conclusion is it is poor oil layer, which products oil of $10.348 \mathrm{t}$ and water of $5.816 \mathrm{~m}^{3}$ for one day after connecting with number 56 layer and the conclusion is that it is high water and high yield industrial reservoir. The result accords with the comprehensive interpretation.

\subsection{Oil-Water Layer Interpretation of 1\# Block}

It can be seen six palm gray oily pink sandstone on the sidewall coring of number 5 of $7 \#$, where oil distribute uniformly and the taste is strong, which presents the oil reservoir characteristics. Geochemical pyrolysis analysis reflects oil abundance is medium, and crude oil has the characteristics of Lightweight oil. Gas chromatography results have the characteristics of oil reservoir or poor layer. Logging interprets the layer as oil reservoir. After pressing to pump, daily oil production is $6.45 \mathrm{~m}^{3}$ and the conclusion is middle-class industry oil reservoir.

\section{Conclusions}

Through application effects analysis, the following conclusions are obtained below:

1) Using quantitative identification assessment method to timely perfect and revise dynamic interpretation plot can greatly improve the comprehensive coincidence rate of oil, gas and water interpretation and realize the fine evaluation of reservoirs.

2) The application and dissemination of oil reservoirs static production potential evaluation method realizes the leap from qualitative interpretation to quantitative interpretation.

3) The design standards for trying oil and selecting fractured layer using quantitative identification assessment method provides evidence for formulating reasonable try oil and fracture solution and technical method for judging the effects of fracture.

4) The method is closely combined with development and production practice and verified in the production and dissemination. Good effects are seen and great economic benefits are created.

\section{Suggestions}

1) For the main blocks of low permeability oilfields which are intensively tapped the potential, because their developmental time is long, currently, comprehensive water content is high, it is suggested that the research in the aspect of water flooded layer interpretation should be done more and hope there will be breakthrough soon.

2) For oil reservoir whose oil-water relationship is very complex, a certain quantity of sidewall coring fluorescent images analysis should be carried out, especially for sidewall coring samples in water flooded layer. The project analysis should be carried out from the key layer in order to improve the interpretation accuracy of water flooded layer.

\section{References}

Lang, D. S., et al. (1994). Reservoir fluid pyrolysis and gas chromatography techniques. Beijing: Petroleum industry press.

Table 1. the standard of $P S$ index and oil production rate rate index $O P I$ identifying properties of crude oil

\begin{tabular}{|c|c|c|}
\hline Geochemical parameters & & \multicolumn{2}{l|}{} \\
\hline Properties of crude oil & $P S$ & $O P I>0.8$ \\
\hline Condensate oil & $P S \geq 5.0$ & $0.6<O P I \leq 0.8$ \\
\hline Lightweight oil & $1.5 \leq P S<5.0$ & $0.3<O P I \leq 0.6$ \\
\hline Intermediate oil & $0.5 \leq P S<1.5$ & $O P I \leq 0.3$ \\
\hline Heavy oil & $P S<0.5$ & \\
\hline
\end{tabular}


Table 2. The interpretation standard of sidewall coring logging data

\begin{tabular}{|c|c|c|c|c|c|c|c|c|c|c|}
\hline $\begin{array}{l}\text { Reservoir } \\
\text { groups }\end{array}$ & $\begin{array}{c}\text { Interpretation } \\
\text { results }\end{array}$ & $\begin{array}{c}\text { Restore } \\
\text { thickness }\end{array}$ & $\begin{array}{l}\text { Oily } \\
\text { color }\end{array}$ & $\begin{array}{c}\text { Full } \\
\text { degree }\end{array}$ & $\begin{array}{l}\text { Oil and } \\
\text { gas taste }\end{array}$ & $\begin{array}{c}\text { Rock } \\
\text { particle } \\
\text { size } \\
\end{array}$ & Property & $\begin{array}{c}\text { Drilling fluid } \\
\text { immersion } \\
\text { depth }\end{array}$ & $\begin{array}{c}\text { Fluorescence } \\
\text { shines }\end{array}$ & $\begin{array}{l}\text { Series } \\
\text { contrast }\end{array}$ \\
\hline \multirow{4}{*}{$\begin{array}{l}\text { Putaohua } \\
\text { and Saert } \\
\text { reservoirs }\end{array}$} & $\begin{array}{c}\text { Oil layer } \\
\text { Poor oil layer }\end{array}$ & $>0.5$ & $\begin{array}{l}\text { brown, gray } \\
\text { brown, } \\
\text { brown brown }\end{array}$ & $\begin{array}{c}\text { Full } \\
\text { A full }\end{array}$ & strong & \begin{tabular}{|c|} 
Mud \\
powder \\
above
\end{tabular} & $\begin{array}{c}\text { Good or } \\
\text { in }\end{array}$ & Deep or in & $\begin{array}{l}\text { Bright } \\
\text { yellow, } \\
\text { yellow }\end{array}$ & $\geq 10$ \\
\hline & $\begin{array}{c}\text { Oil and water } \\
\text { layer }\end{array}$ & $>0.5$ & $\begin{array}{l}\text { gray brown, } \\
\text { brown gray }\end{array}$ & $\begin{array}{l}\text { Own } \\
\text { full }\end{array}$ & $\begin{array}{l}\text { Has or } \\
\text { weak }\end{array}$ & \begin{tabular}{|c|} 
Mud \\
powder \\
above
\end{tabular} & $\begin{array}{c}\text { Good or } \\
\text { in }\end{array}$ & Deep or in & $\begin{array}{c}\text { Yellow, pale } \\
\text { yellow }\end{array}$ & $\geq 8$ \\
\hline & Water layer & $>0.5$ & $\begin{array}{l}\text { brown gray } \\
\text { or no }\end{array}$ & $\begin{array}{c}\text { Own } \\
\text { full or } \\
\text { no }\end{array}$ & $\begin{array}{c}\text { Weak or } \\
\text { no }\end{array}$ & \begin{tabular}{|c} 
Mud \\
powder \\
above
\end{tabular} & $\begin{array}{c}\text { Good or } \\
\text { in }\end{array}$ & Deep & $\begin{array}{l}\text { Pale yellow } \\
\text { or no }\end{array}$ & I \\
\hline & Dry layer & I & $\begin{array}{l}\text { brown gray } \\
\text { or no }\end{array}$ & \begin{tabular}{|c|} 
Own \\
full or \\
no
\end{tabular} & $\begin{array}{c}\text { Weak or } \\
\text { no }\end{array}$ & $\begin{array}{c}\text { Mud } \\
\text { powder }\end{array}$ & $\mathrm{Bad}$ & Shallow & $\begin{array}{l}\text { Pale yellow } \\
\text { or no }\end{array}$ & I \\
\hline
\end{tabular}

Table 3. Interpretation parameters of Putaohua reservoir in western region

\begin{tabular}{|c|c|c|c|c|c|c|c|c|c|c|c|c|c|c|}
\hline \multirow{2}{*}{$\begin{array}{c}\text { Comprehensiv } \\
\mathrm{e} \\
\text { interpretation }\end{array}$} & \multicolumn{3}{|c|}{$\begin{array}{c}\text { Sidewall coring } \\
\text { physical observation }\end{array}$} & \multirow{2}{*}{$\begin{array}{c}\text { Effectiv } \\
\mathrm{e} \\
\text { thicknes } \\
\mathrm{s} \\
\mathrm{m}\end{array}$} & \multicolumn{2}{|c|}{$\begin{array}{c}\text { Geochemic } \\
\text { al pyrolysis } \\
\text { analysis } \\
\end{array}$} & \multicolumn{2}{|c|}{$\begin{array}{l}\text { Organic } \\
\text { carbon } \\
\text { analysis }\end{array}$} & \multicolumn{6}{|c|}{ Gas chromatographic analysis } \\
\hline & \begin{tabular}{|c} 
Oil \\
full \\
degre \\
$\mathrm{e}$
\end{tabular} & Uniform & $\begin{array}{c}\text { Water } \\
\text { cut } \\
\text { feature } \\
\mathrm{s}\end{array}$ & & $\begin{array}{c}\mathrm{S}_{\mathrm{T}} \\
\mathrm{mg} / \mathrm{g}\end{array}$ & $\mathrm{S}_{1} / \mathrm{S}_{2}$ & $\begin{array}{l}\Phi e \\
\%\end{array}$ & $\begin{array}{l}\mathrm{S}_{0} \\
\%\end{array}$ & $\begin{array}{l}\text { Peak } \\
\text { shape }\end{array}$ & $\begin{array}{l}\text { The } \\
\text { vault } \\
\text { range }\end{array}$ & $\mathrm{Pr} / \mathrm{Ph}$ & $\mathrm{Pr} / \mathrm{C}_{17}$ & $\mathrm{Ph} / \mathrm{C}_{18}$ & $\sum \mathrm{C}_{21}{ }^{-} / \sum \mathrm{C}_{22}$ \\
\hline Oil layer & Full & $\begin{array}{c}\text { Relativel } \\
\mathrm{y} \\
\text { uniform }\end{array}$ & No & $>1.2$ & $>15$ & $>1.5$ & $>18$ & $>30$ & $\begin{array}{c}\text { Normal } \\
\text { triangula } \\
\mathrm{r}\end{array}$ & No & $<1.2$ & $<0.24$ & $<0.24$ & $>1.2$ \\
\hline Poor oil layer & A full & 1 Not even & No & $>0.6$ & $>10$ & $>1.2$ & $\begin{array}{c}15 \sim 2 \\
0\end{array}$ & $\begin{array}{c}20 \sim 5 \\
0\end{array}$ & $\begin{array}{c}\text { Normal } \\
\text { or front } \\
\text { triangula } \\
\mathrm{r}\end{array}$ & No & $\begin{array}{c}1.0 \sim 1 . \\
3\end{array}$ & $\begin{array}{c}0.20 \sim 0.2 \\
6\end{array}$ & $\begin{array}{c}0.20 \sim 0.2 \\
4\end{array}$ & $>0.8$ \\
\hline $\begin{array}{c}\text { Oil and water } \\
\text { layer }\end{array}$ & $\begin{array}{l}\text { Own } \\
\text { full }\end{array}$ & $\begin{array}{c}\text { Spots } \\
\text { crumb } \\
\text { oil }\end{array}$ & $\begin{array}{c}\text { Water } \\
\text { cut } \\
\text { more } \\
\text { obviou } \\
\text { s }\end{array}$ & $>0.6$ & $<17$ & $<1.5$ & $>15$ & $<40$ & $\begin{array}{c}\text { After or } \\
\text { before } \\
\text { triangle }\end{array}$ & $\begin{array}{c}\text { eviden } \\
\mathrm{t}\end{array}$ & $>1.0$ & $>0.20$ & $>0.20$ & $<1.2$ \\
\hline Water layer & $\begin{array}{c}\text { Oil } \\
\text { dry or } \\
\text { no }\end{array}$ & & $\begin{array}{c}\text { Water } \\
\text { cut } \\
\text { obviou } \\
\text { s }\end{array}$ & $>0.6$ & $<10$ & $<1.2$ & $>15$ & $<30$ & $\begin{array}{c}\text { Low } \\
\text { amplitud } \\
\text { e after } \\
\text { the } \\
\text { triangle } \\
\end{array}$ & $\begin{array}{c}\text { eviden } \\
\mathrm{t}\end{array}$ & $>1.0$ & $>0.26$ & $>0.24$ & $<1.2$ \\
\hline Dry layer & / & / & No & / & $<10$ & $<1.0$ & $<15$ & $<20$ & bit & No & / & / & / & l \\
\hline
\end{tabular}


Table 4. Try oil production and perforation verification results table

\begin{tabular}{|c|c|c|c|c|c|c|c|c|c|c|c|}
\hline Block & $\begin{array}{c}\text { Number } \\
\text { of already } \\
\text { try oil } \\
\text { wells of } \\
\text { evaluation } \\
\text { wells }\end{array}$ & $\begin{array}{c}\text { Number } \\
\text { of try } \\
\text { oil layer }\end{array}$ & $\begin{array}{c}\text { Number } \\
\text { of } \\
\text { meeting } \\
\text { layers }\end{array}$ & $\begin{array}{c}\text { Coincidence } \\
\text { rate } \%\end{array}$ & $\begin{array}{c}\text { Number of } \\
\text { ring test } \\
\text { wells of the } \\
\text { development } \\
\text { wells }\end{array}$ & $\begin{array}{c}\text { Number } \\
\text { of test } \\
\text { layers }\end{array}$ & $\begin{array}{c}\text { Number } \\
\text { of } \\
\text { meeting } \\
\text { layers }\end{array}$ & $\begin{array}{c}\text { Coincidence } \\
\text { rate } \%\end{array}$ & $\begin{array}{c}\text { Number of } \\
\text { production } \\
\text { wells } \\
\text { without } \\
\text { ring test }\end{array}$ & $\begin{array}{c}\text { Number } \\
\text { of } \\
\text { meeting } \\
\text { wells }\end{array}$ & $\begin{array}{c}\text { Coincidence } \\
\text { rate } \%\end{array}$ \\
\hline 1\# & 3 & 6 & 4 & 66.7 & 5 & 15 & 11 & 73.3 & 22 & 19 & 86.4 \\
\hline $2 \#$ & 7 & 19 & 15 & 78.9 & & & & & & & \\
\hline $3 \#$ & 4 & 7 & 4 & 57.1 & & & & & & & \\
\hline 4\# & 14 & 32 & 23 & 71.9 & 5 & 15 & 11 & 73.3 & 24 & 20 & 83.3 \\
\hline Total & 14 & & & & & & & & & & \\
\hline
\end{tabular}

Table 5. The compare table between try oil results of evaluation well and comprehensive interpretation results of logging

\begin{tabular}{|c|c|c|c|c|c|c|c|c|c|c|}
\hline Well & Layer & $\begin{array}{c}\text { Comprehensive } \\
\text { interpretation }\end{array}$ & Conformance & 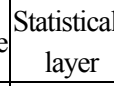 & Right & Wrong & Try oil way & Oil(t) & Water $\left(\mathrm{m}^{3}\right)$ & Try oil conclusion \\
\hline 1 & $3-6$ & Poor oil layer & $\sqrt{ }$ & 4 & 4 & & After pressing to pump & 2.57 & \multirow{3}{*}{55.2} & Low reservoir \\
\hline \multirow{3}{*}{2} & $2-4$ & Water layer & $\sqrt{ }$ & \multirow{2}{*}{4} & 3 & & \multirow{2}{*}{ After pressing to pump } & \multirow{2}{*}{4.339} & & \multirow{2}{*}{ Oily water reservoir } \\
\hline & 5 & Water layer & $\times$ & & & 1 & & & & \\
\hline & 8 & Poor oil layer & $\sqrt{ }$ & 1 & 1 & & After pressing to pump & 0.363 & & Low reservoir \\
\hline 3 & 37 & Oil and water layer & $\sqrt{ }$ & 1 & 1 & & MFE-II+pump & showings & 8.8 & Oily water reservoir \\
\hline 4 & 26 & Oil layer & $\sqrt{ }$ & 1 & 1 & & Natural flow & 5.73 & & Hydrocarbon reservoir \\
\hline \multirow{3}{*}{5} & $49-50$ & Poor oil layer & $\sqrt{ }$ & 2 & 2 & & After pressing to pump & 1.132 & & Low reservoir \\
\hline & 54 & Poor oil layer & $\sqrt{ }$ & \multirow{2}{*}{2} & \multirow{2}{*}{2} & & \multirow{2}{*}{ After pressing to pump } & \multirow{2}{*}{3.636} & & \multirow{2}{*}{ Industrial reservoir } \\
\hline & 58 & Oil layer & $\sqrt{ }$ & & & & & & & \\
\hline \multirow{3}{*}{6} & 1 & Oil and water layer & $x$ & 1 & & 1 & MFE- II + pump & & 0.673 & Low water layer \\
\hline & 7 & Water layer & $\sqrt{ }$ & 1 & 1 & & MFE- II +pump & 0.031 & 7.947 & Oily water reservoir \\
\hline & $8-9$ & Dry layer & $x$ & 2 & & 2 & After pressing to pump & 5.945 & & Industrial reservoir \\
\hline \multirow{2}{*}{7} & 3 & Oil layer & $\sqrt{ }$ & \multirow{2}{*}{2} & 1 & & \multirow{2}{*}{ After pressing to pump } & \multirow{2}{*}{$6.4 \mathrm{~m}^{3}$} & & \multirow{2}{*}{ Industrial reservoir } \\
\hline & 4 & Water layer & $x$ & & & 1 & & & & \\
\hline \multirow{4}{*}{8} & 1 & Water layer & $x$ & 1 & & 1 & pump & $0.24 \mathrm{~m}^{3}$ & 0.75 & Low oil and water layer \\
\hline & 2 & Oil and water layer & $\sqrt{ }$ & 1 & 1 & & MFE-II + pump & $0.088 \mathrm{~m}^{3}$ & 0.45 & Low oil and water layer \\
\hline & 3 & Poor oil layer & $\sqrt{ }$ & 1 & 1 & & \multirow{2}{*}{ After pressing to pump } & \multirow{2}{*}{$0.54 \mathrm{~m}^{3}$} & \multirow{2}{*}{1.23} & \multirow{2}{*}{ Oily water reservoir } \\
\hline & 4 & Dry layer & ○ & & & & & & & \\
\hline 9 & 8 & Oil layer & $\sqrt{ }$ & 1 & 1 & & After pressing to pump & $6.36 \mathrm{~m}^{3}$ & & Industrial reservoir \\
\hline 10 & 4 & Water layer & $x$ & 1 & & 1 & pump / After pressing to pum! & $0.83 \mathrm{~m}^{3} / 3.78 \mathrm{~m}^{3}$ & $30.36 / 8.70$ & Oily water reservoir \\
\hline \multirow{2}{*}{11} & $1 \mathrm{II}$ & Poor oil layer & $\sqrt{ }$ & 1 & 1 & & \multirow{2}{*}{ pump } & \multirow{2}{*}{$0.58 \mathrm{t}$} & \multirow{2}{*}{0.58} & \multirow{2}{*}{ Low oil and water layer } \\
\hline & $2 \mathrm{II}$ & Poor oil layer & $\times$ & 1 & & 1 & & & & \\
\hline \multirow{3}{*}{12} & 1 & Oil and water layer & $\sqrt{ }$ & \multirow{2}{*}{2} & 2 & & numn & 298 & 045 & Water_cut oil lavers \\
\hline & 3 & Poor oil layer & $\sqrt{ }$ & & 2 & & pump & 2.90 & 0.45 & Waler-cut on layers \\
\hline & 9 & Oil and water layer & $\times$ & 1 & & 1 & pump & & 5.2 & Water layer \\
\hline 13 & 5 & Oil layer & $\sqrt{ }$ & 1 & 1 & & pump & 16.5 & & Industrial reservoir \\
\hline & otal & & & 32 & 23 & 9 & Coincidence rate $71.9 \%$ & & & \\
\hline
\end{tabular}




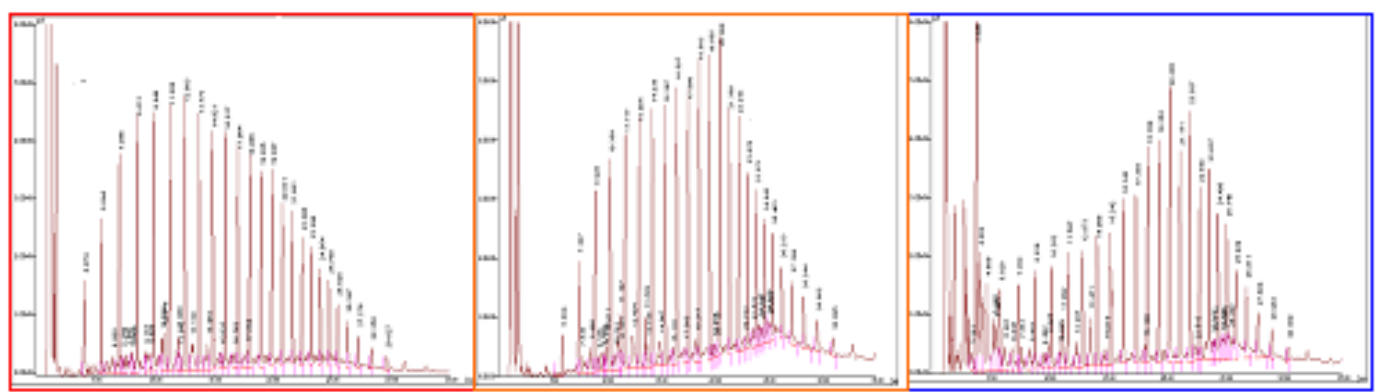

$\begin{array}{lll}\text { 1) Oil layer chromatogram } & \text { 2) Oil and water layer chromatogram } & \text { 3) Water layer chromatogram }\end{array}$ Figure 1. Characteristics of Gas Chromatogram for Reservoirs with Different Liquid Properties

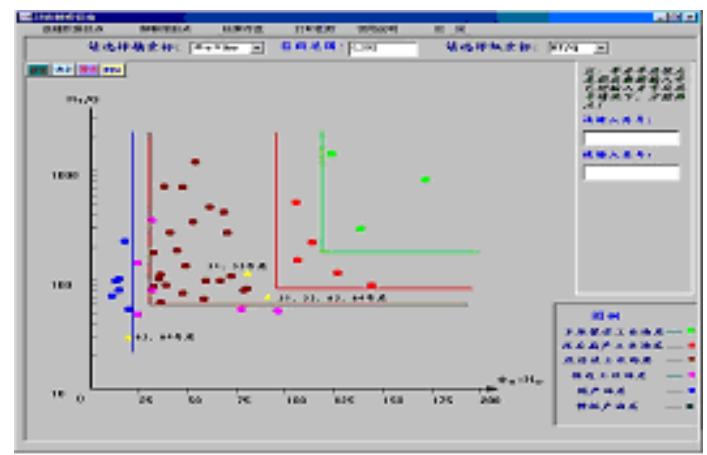

Figure 2. Productivity plate of $1 \#$ oil layer

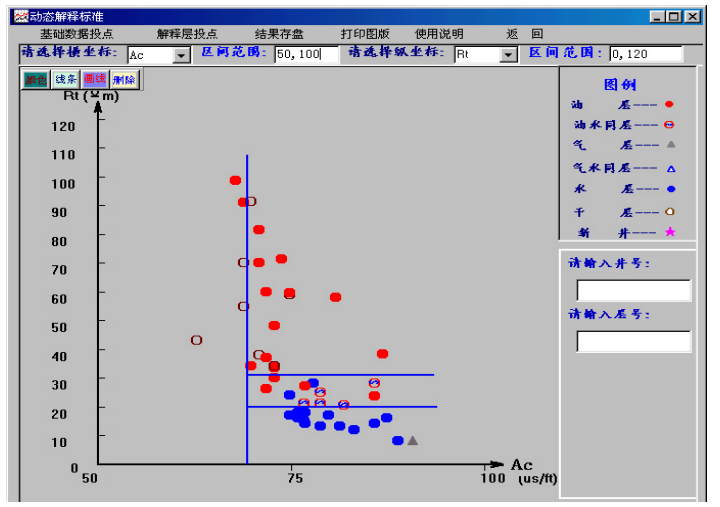

Figure 3. Oil dynamic interpretation plate of $2 \#$ block 


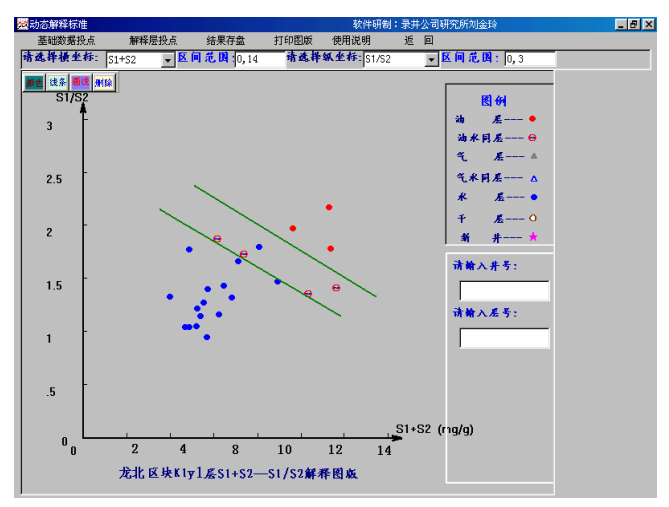

Figure 4. Oil dynamic interpretation plate of 3\# block

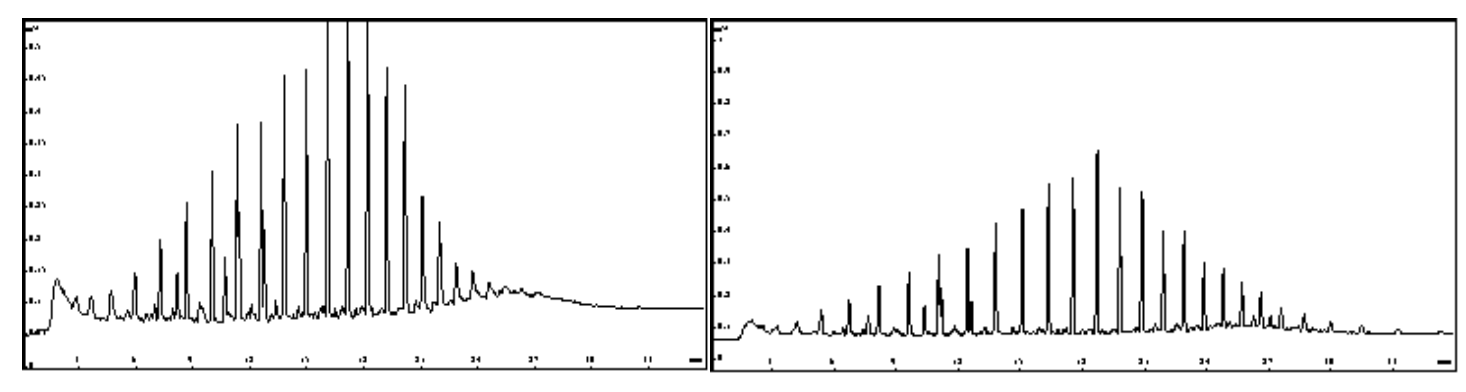

Gas chromatography of number 56 layer;

Gas chromatography of number 58 layer

Figure 5. Gas chromatography of number 56 and 58 layers

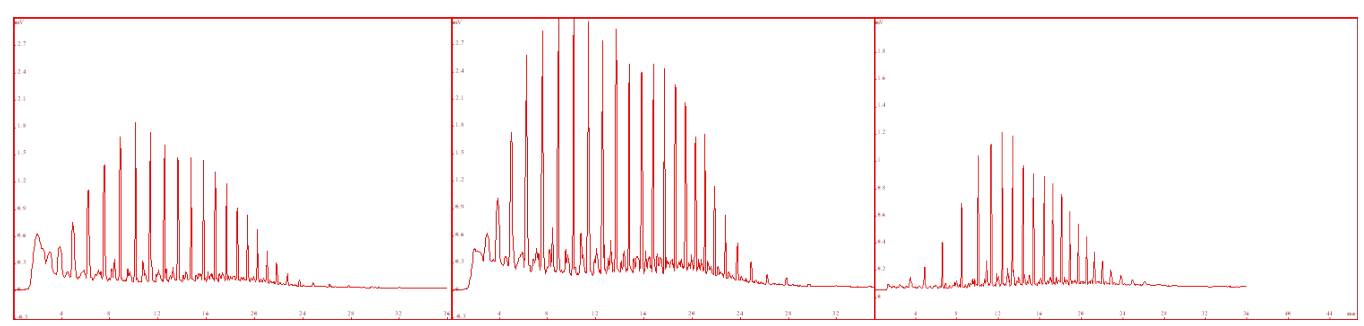

Figure 6. Gas chromatogram of number 5 of 7\# 